\title{
Penetration of trimethoprim and sulphamethoxazole into the aqueous humour
}

\author{
P. E. J. POHJANPELTO, T. J. SARMELA, AND T. RAINES \\ From the Eye Department of the Regional Hospital, Lahti, and Research Centre, Lääke-Medipolar, \\ Turku
}

Trimethoprim (TM) (2,4-diamino-5-(3,4,5-trimethoxybenzyl)-pyrimidine) is an antibacterial agent. It blocks the folic acid synthesis of bacteria in the manner of the sulphonamides, but acts at a different stage in the synthesis. TM and sulphonamides have a synergistic effect (Bushby and Hitchings, 1968), and thus a combination of TM and sulphonamide has a broad-spectrum bactericidal action (Böhni, I969). The sulphonamide used in combined preparations has been sulphamethoxazole (SMZ) which in man has practically the same rate of secretion and elimination as TM, the half-life of both being approximately ro hrs (Rieder, I963; Schwartz and Ziegler, 1969).

TM and SMZ have been found to diffuse well into different tissues (Schwartz and Rieder, 1970) and it therefore seemed possible that they would also penetrate the bloodaqueous barrier. The purpose of our work was to study this question in rabbit and human eyes.

\section{Methods}

The experiments on the test animals were conducted in the Research Centre Lääke-Medipolar, Turku. The test animals were eight male albino rabbits weighing $2 \cdot 5-3.9 \mathrm{~kg}$. They were given $20 \mathrm{mg}$. $\mathrm{TM}$ and roo $\mathrm{mg}$. SMZ per kg. body weight in a single oral dose. The aqueous sample and the blood sample from the auricular vein were taken from four rabbits 1 hour and from the other four 2 hours after administration of the drug. Puncture of the anterior chamber was performed at the limbus, using a disposable No. 18 needle. The animals were anaesthetized with nembutal for the sampling.

The human samples were taken at the Eye Department of the Regional Hospital, Lahti. An oral dose of $160 \mathrm{mg}$. TM and $800 \mathrm{mg}$. SMZ (Trimosulfa, Lääke Oy) was given to six patients the evening before surgery for cataract and was repeated on the following morning. Before the first dose, blood was drawn from the cubital vein for the control sample, and 2 hours after the second dose, during the cataract operation, about $0.2 \mathrm{ml}$. aqueous was withdrawn under retrobulbar anaesthesia. The aqueous was drawn off with a disposable No. 18 needle which was inserted through the cornea at the limbus. The amount of fluid removed was replaced with physiological saline and the cataract extraction was performed in the usual way. A blood sample was taken from the cubital vein while the retrobulbar anaesthetic was taking effect.

The samples were frozen, heat-insulated, packed in carbon-dioxide ice, and sent in a single consignment from Lahti to the Research Centre Lääke-Medipolar, Turku, where the drug determinations were made. 
SMZ was determined chemically by spectrophotometry (Bratton and Marshall, 1939).

TM was assayed by an agar plate diffusion technique using Bacillus pumilus as the test organism. The zone diameters of inhibition were measured and compared to standards after the plates had been incubated at $37^{\circ} \mathrm{C}$ for about $18 \mathrm{hrs}$. The standard solutions used for the aqueous assays were 0.8 , $0.5,0.25,0.15$, and $0.10 \mu \mathrm{g} . / \mathrm{ml}$. and for the serum assays $0.5,0.25,0.15,0.10,0.05$, and 0.025 $\mu \mathrm{g} . / \mathrm{ml}$. The sensitivity of the assays was slightly below the lowest standard point.

\section{Results}

The results of the rabbit tests are presented in Table I. Penetration of TM into the aqueous was demonstrable in all but one test animal. The concentration in the aqueous was 9 to 21 per cent of the serum level. SMZ penetrated into the aqueous in all the test animals and the concentration was from 9 to 2 I per cent. of the serum concentration.

Table I Serum and aqueous levels $(\mu g . / \mathrm{ml}$.) of trimethoprim and sulphamethoxazole in rabbits

\begin{tabular}{|c|c|c|c|c|c|}
\hline \multirow{2}{*}{$\begin{array}{l}\text { Case } \\
\text { no. }\end{array}$} & \multirow{2}{*}{$\begin{array}{l}\text { Hours } \\
\text { after } \\
\text { dose }\end{array}$} & \multicolumn{2}{|c|}{ Trimethoprim } & \multicolumn{2}{|c|}{ Sulphamethoxazole } \\
\hline & & Serum & Aqueous & Serum & Aqueous \\
\hline I & I & $4 \cdot 03$ & $0 \cdot 37$ & 65 & Io \\
\hline 2 & I & $2 \cdot 68$ & $0 \cdot 36$ & 44 & 7 \\
\hline 3 & I & $\mathrm{I} \cdot 4^{\mathrm{I}}$ & $0 \cdot 43$ & 30 & 6 \\
\hline 4 & I & $2 \cdot 40$ & $0 \cdot 50$ & 120 & 15 \\
\hline 5 & 2 & $0 \cdot 37$ & $<0 \cdot 1$ & 48 & I0 \\
\hline 6 & 2 & $\mathrm{I} \cdot 07$ & O.II I & I 78 & 25 \\
\hline 7 & 2 & $\mathrm{I} \cdot \mathrm{I} 5$ & $0 \cdot 20$ & 80 & 7 \\
\hline 8 & 2 & $\mathrm{I} \cdot 02$ & 0.00 & 78 & 7 \\
\hline
\end{tabular}

The results for the samples taken from the cataract patients are given in Table II. Table II Serum and aqueous levels $(\mu \mathrm{gg} / \mathrm{ml}$.) of trimethoprim and sulphamethoxazole in cataract patients

\begin{tabular}{|c|c|c|c|c|c|c|c|c|}
\hline \multirow{2}{*}{$\begin{array}{l}\text { Patient } \\
\text { no. }\end{array}$} & \multirow[t]{2}{*}{ Sex } & \multirow{2}{*}{$\begin{array}{l}\text { Weight } \\
(\mathrm{kg} .)\end{array}$} & \multicolumn{3}{|c|}{ Trimethoprim } & \multicolumn{3}{|c|}{ Sulphamethoxazole } \\
\hline & & & Control & Serum & Aqueous & Control & Serum & Aqueous \\
\hline$I^{*}$ & $\mathbf{F}$ & $44 \cdot 5$ & o & I·95 & $0 \cdot 33$ & o & 83 & rot \\
\hline 2 & $\mathbf{F}$ & 71 & 0 & $2 \cdot 00$ & $0 \cdot 19$ & o & 72 & $20 \dagger$ \\
\hline 3 & $\mathbf{M}$ & 68 & 0 & $\mathrm{I} \cdot 40$ & $0 \cdot 2 \mathrm{I}$ & o & 55 & Iot \\
\hline 4 & $\mathbf{M}$ & $60 \cdot 5$ & o & $2 \cdot 85$ & 0.40 & o & I 34 & 29 \\
\hline 5 & $\mathrm{~F}$ & 63 & o & 0.76 & $0 \cdot 14$ & o & 30 & $20 \dagger$ \\
\hline 6 & $\mathbf{M}$ & 73 & o & $\mathrm{I} \cdot 4^{8}$ & $0 \cdot 22$ & o & I 18 & 15 \\
\hline
\end{tabular}

* Because of a technical failure the blood sample was taken on a different day but in the same conditions as the aqueous sample. tThe aqueous samples of Patients 1 and 3 and of Patients 2 and 5 were pooled for the determination of sulphamethoxazole. The figure refers to the concentration of the mixture.

Allowing for synergism, therapeutic amounts of TM (Böhmi, I969) were demonstrable in the aqueous of all the patients. The TM concentration was io to i 8 per cent. of the serum level. Unfortunately it was possible to carry out an individual determination of SMZ for only two patients. Because of the smallness of the samples, two samples of the other four 
patients had to be pooled for the determination of the SMZ concentration, but it appears that this also achieved an adequate level in all the patients.

\section{Discussion}

Two tablets twice daily (one tablet $=80 \mathrm{mg}$. TM and $400 \mathrm{mg}$. SMZ) is the recommended normal dosage of TM and SMZ compounds. When this dosage was administered, both drugs were demonstrated in the aqueous of cataract patients in therapeutically effective concentrations.

It has been noted in many connections that the permeability of the blood-aqueous barrier is increased in an inflamed eye, and that drugs achieve a higher concentration in an inflamed than in a normal eye (Tsakopoulos, I969; Krause, Raunio, and Mustonen, I972 ; Barza, Baum, Birkby, and Weinstein, I973). It is therefore probable that the TM and SMZ concentrations in the eye are also higher during inflammation than the values now established.

Combination of TM and SMZ is a possibility worth considering when a broad-spectrum antibacterial effect is required intraocularly.

\section{Summary}

The penetration of trimethoprim (TM) and sulphamethoxazole (SMZ) into the aqueous humour was studied in rabbits and with the recommended normal dosage in six patients with cataract. Both drugs were demonstrated in therapeutically effective amounts in the aqueous of both the test animals and the human patients.

\section{References}

barza, M., Baum, J., Birkby, в. and weinstein, L. (1973) Amer. F. Ophthal., 75, 307

BöHni, Е. (г969) Chemotherapy, r4, Suppl. I

BRATton, A. C., and MARshall, E. K. (1939) 7. biol. Chem., 128, 537

Bushby, s. R. M., and hitchings, G. H. (1968) Brit. F. Pharmacol., 33, 72

krause, u., raunio, v., and mustonen, e. (1972) Amer. F. Ophthal., 74, 77

RIEDER, J. (1963) Arzneim. Forsch., 13, 8I

SCHWARTZ, D. E., and RIEDER, J. (1970) Chemotherapy, 15, 337

- and ziegler, w. H. (ig69) Postgrad. med. F., 45, Nov. Suppl., p. 32

TSAKopoulos, M. (1969) Ophthalmologica (Basel), r59, 4 18. 